\title{
Escherichia coli Harbouring Resistance Genes, Virulence Genes and Integron 1 Isolated from Athi River in Kenya
}

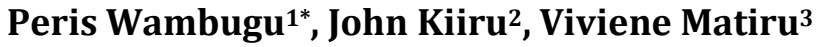 \\ ${ }^{1}$ Institute of Tropical Medicine and Infectious Diseases, Jomo Kenyatta University of Agriculture and Technology, Nairobi, Kenya \\ ${ }^{2}$ Centre of Microbiology Research, Kenya Medical Research Institute, Nairobi, Kenya \\ ${ }^{3}$ Department of Botany, Sub-Department of Medical Microbiology, Jomo Kenyatta University of Agriculture and Technology, \\ Nairobi, Kenya \\ Email: *perhizz@yahoo.com
}

How to cite this paper: Wambugu, P., Kiiru, J. and Matiru, V. (2018) Escherichia coli Harbouring Resistance Genes, Virulence Genes and Integron 1 Isolated from Athi River in Kenya. Advances in Microbiology, 8, 846-858.

https://doi.org/10.4236/aim.2018.811056

Received: January 18, 2018

Accepted: November 4, 2018

Published: November 7, 2018

Copyright (c) 2018 by authors and Scientific Research Publishing Inc. This work is licensed under the Creative Commons Attribution International License (CC BY 4.0)

http://creativecommons.org/licenses/by/4.0/

\begin{abstract}
Rivers can act as reservoirs of highly resistant strains and facilitate the dissemination of resistance, virulence and integron 1 genes. A cross-sectional study was carried out where 318 water samples were collected (53 from each site) and from the samples, $318 \mathrm{E}$. coli isolates were analysed for resistance genes, virulence genes and integron 1 using Polymerase Chain Reaction. 22\% of the isolates had $b l a_{T E M}, 33 \%$ had $b l a_{C T X-M}$ and $28 \%$ had $b l a_{C M Y}$. Prevalence of typical Enteropathogenic E. coli strains (carrying both eae and bfp genes) was $5 \%$ while the prevalence of atypical Enteropathogenic E. coli (carying only eae) was $1.8 \%$. The prevalence of Enteroaggregative $E$. coli carrying the aggr genes was $11 \%$. The prevalence of Enterotoxigenic E. coli encoding only lt toxin was $16(5 \%)$ and while those carrying only st toxin was $6.9 \%$. The prevalence of Enteroinvasive E. coli strains encoding as IpaH was $5 \%$ while that of strains, adherent invasive $E$. coli, carrying adherent invasive gene inv was $8.7 \%$. 36\% isolates were positive for class 1 integrons which were mostly isolated near the sewage effluent from waste treatment plant. Anthropogenic activities and close proximity to sewage treatment plant were found to play a key role in pollution of water body and accumulation of resistance and virulence genes. These results suggest that waste treatment plant may act as reservoir of resistance, virulence and integron 1 genes and is a potential risk to human and animal health in the region.
\end{abstract}

\section{Keywords}

Athi River, E. coli, Integron 1, Resistance Genes, Virulence Genes 


\section{Introduction}

Water bodies and aquatic systems have great potential as sources of infectious bacteria to people who use the water for recreational activities, fishing, drinking, bathing and irrigation of crops, especially those eaten raw [1]. E. coli is an important indicator organism for fecal pollution in environmental waters and has also been useful in monitoring antimicrobial resistance patterns in gram-negative bacteria and pollution of water bodies with resistance and virulence genes, especially those suspected to be of human origin requires evaluation [2] [3]. Some $E$. coli strains have acquired virulence genes that allow them to cause various infections such as diarrhea and hemolytic-uremic syndrome (HUS). If such pathotypes find their way into the water systems, their potential for spread could be multiplied. Clinical isolates can find their way into water systems through fecal matter from humans and animals. This is particularly the case if the sewerage systems are not properly designed or where water treatment is poor.

The presence of antimicrobial resistance genes on mobile genetic elements leads to their dissemination and possible development of multi-resistance phenotype. The dissemination of resistance is associated with genetic mobile elements, such as plasmids, that may also carry virulence determinants. A combination of resistance genes and virulence factors enable a host to replicate and disseminate these genes to other hosts with ease. As a result of using antimicrobials, bacteria can evolve resistance that can be passed to commensal and other pathogens sharing the same ecosystem, e.g. the human gut. It is assumed that virulent MDR strains are more difficult to control than other strains and this impacts on patient's chemotherapeutic success. Presence of such bacteria in healthcare, animal and environmental setting is a major public health concern because such bacteria are highly virulent and untreatable using antimicrobials [4].

The ability of $E$. coli to carry plasmid-borne integron 1 suggests that the encoded antimicrobial resistance genes can easily be transferred among bacteria and even between pathogenic commensal strains and environment $E$. coli trains. It is of interest to note that if such highly resistant strains enter aquatic systems; their chance of spread is highly increased.

Rivers and aquatic systems are important environments for exchange of resistance determinants among enteric and environmental isolates due to activities along a water body such as drainage of sewage containing heavy metal that results in natural selection of resistant strains, humans extensive use of antibiotics in agriculture and health that promote displacement of susceptible strains with resistant ones which find their way to the aquatic environments as well as use of detergents which can select for MDR strains in sections of rivers where domestic activities such as washing clothes and household items with detergents take place [5].

Athi River in Machakos county is a heavily polluted water system mainly as a result of contamination from sewerage originating from Westlands and Kasarani 
areas in Nairobi [6]. However, little is known about the genetic basis of resistance from this river. The aim of this cross-sectional study was therefore to determine the molecular basis of resistance to selected antimicrobials and carriage of virulence genes and integron 1 gene among the isolates.

\section{Materials and Methods}

The study was carried out along the banks of River Athi within the Athi River Township in Machakos County as shown in Figure 1.

\subsection{Sampling}

The sampling points were selected based on prevailing human activities such as washing, drinking points for livestock, points where residents fetch water for domestic use, and points heavily contaminated with industrial effluent. Sampling was also done along sections of the river passing through virgin lands that have no obvious evidence of recent interference by human activity, agriculture or settlement as shown in Figure 1.

Water samples were collected from each site in varying dates between September 2014 and January 2015. Sampling of each site was done only once. The samples were transported to Kenya Medical Research Institute Centre for Microbiology laboratory in an insulated cool box $\left(4^{\circ} \mathrm{C}-8^{\circ} \mathrm{C}\right)$ and processed within 24 hrs.

\subsection{Isolation of $E$. coli}

For isolation of E. coli, $25 \mathrm{ml}$ of sample water was inoculated into $225 \mathrm{~mL}$ of buffered peptone water (BPW) (Oxoid, UK) and incubated at $37^{\circ} \mathrm{C}$ for $24 \mathrm{hrs}$. A loop-full of broth $(10 \mu \mathrm{l})$ was then streaked on MacConkey's agar (Oxoid, UK)

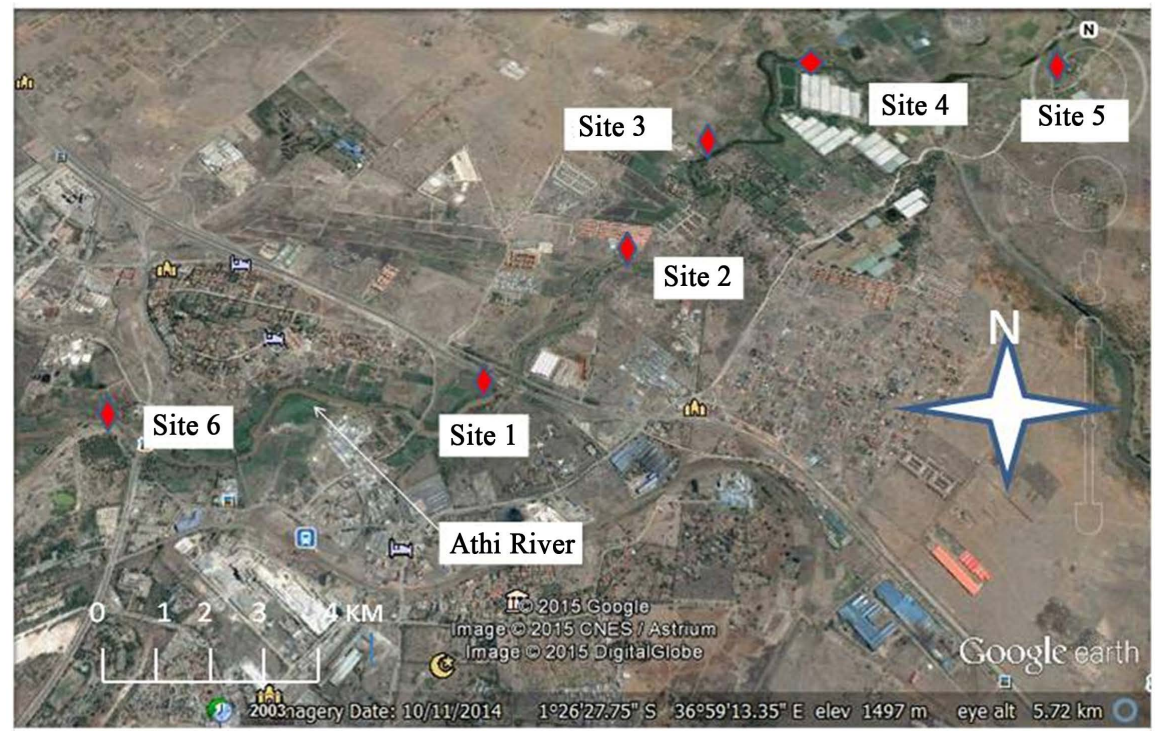

Figure 1. Aerial view of sampling sites along Athi River in Athi River Town, Machakos from Google Earth. 
and incubated at $37^{\circ} \mathrm{C}$ for $24 \mathrm{hrs}$. Suspect colonies (medium sized pink non-mucoid colonies) were then picked from the plates by use of sterile wire loop and identified as E. coli using standard morphological and biochemical tests for Enterobacteriaceae.

Pure colonies of each isolate selected for further analysis were suspended in $300 \mu \mathrm{l}$ of DNA extraction buffer and boiled for 15 minutes at $95^{\circ} \mathrm{C}$ using a heating block. After lysis, centrifugation was done at $14,000 \mathrm{rmp}$ for 5 minutes at $4^{\circ} \mathrm{C}$. The DNA containing supernatant was stored in $-20^{\circ} \mathrm{C}$ and later used as the source of DNA template for further PCR amplification experiments [7].

\subsection{PCR Amplification}

PCR amplification was carried out using quagen PCR kit. The thermo-cycler PCR conditions were primer specific. Table 1 shows the PCR annealing temperatures and primers used. The accession numbers are also included in the table as well as reference articles from which other primers were designed from for amplification of those specific genes [8] [9] [10] [11].

Table 1. PCR primers and annealing temperatures used in amplification of genes.

\begin{tabular}{|c|c|c|c|c|c|}
\hline $\begin{array}{l}\text { Oligonucleotide } \\
\text { name }\end{array}$ & Oligonucleotide 5'-3' & $\begin{array}{l}\text { Target } \\
\text { gene }\end{array}$ & $\begin{array}{l}\text { PCR annealing } \\
\text { temperature }\end{array}$ & $\begin{array}{l}\text { Amplification } \\
\text { product (bp) }\end{array}$ & $\begin{array}{c}\text { Accession } \\
\text { number/reference }\end{array}$ \\
\hline \multicolumn{6}{|c|}{ Resistance genes } \\
\hline$b l a_{T E M}$ & $\begin{array}{l}\text { ATGAGTATTCAACAT TTC CG-F } \\
\text { CCAATGCTTAATCAG TGA-R }\end{array}$ & $b l a_{T E M}$ & 53.5 & 840 & EF125012 \\
\hline $\mathrm{cmy}$ & $\begin{array}{l}\text { ATGATGAAAAAATCGTTATGC-F } \\
\text { TTGCAGCTTTTCAAGAATGCG-R }\end{array}$ & $B l a_{C M Y \mathrm{~s}}$ & 55 & 1200 & U77414 \\
\hline Ctx-m & $\begin{array}{l}\text { ATGTGCAGYACCAGTAARGTK-F } \\
\text { ATGGCRAARTARGTSACCAGA-R }\end{array}$ & $B \operatorname{Ba}_{C T X-M}$ & 60 & 593 & Y10278 \\
\hline eae & $\begin{array}{l}\text { CTGAACGGCGATTACGCGAA-F } \\
\text { CGAGAGACGATACGATCCAG-R }\end{array}$ & eae & 54 & 917 & {$[8]$} \\
\hline bfp & $\begin{array}{l}\text { AATGGTGCTTGCGCTTGCTGC-F } \\
\text { GCCGCTTTATCCAACCTGGTA-R }\end{array}$ & bfp & 54 & 326 & {$[8]$} \\
\hline \multicolumn{6}{|c|}{ Virulence genes } \\
\hline Aggr & $\begin{array}{l}\text { GTATACACAAAGAAGGAAGC-F } \\
\text { ACAGAATCGTCAGCATCAGC-R }\end{array}$ & $\begin{array}{l}\text { Aggrks a1, } \\
\text { Aggrks a2 }\end{array}$ & 54 & 254 & {$[8]$} \\
\hline lt & $\begin{array}{l}\text { GCACACGGAGCTCCTCAGTC-F } \\
\text { TCCTTCATCCTTTCAATGGCTTT-R }\end{array}$ & lt & 54 & 218 & [9] \\
\hline st & $\begin{array}{l}\text { GCTAAACCAGTAGASTCTTCAAAA-F } \\
\text { CCCGGTACARGCAGGATTACAACA-R }\end{array}$ & st & 54 & 147 & {$[10]$} \\
\hline Ipa $\mathrm{H}$ & $\begin{array}{l}\text { CTCGGCACGTTTTAATAGTCTGG-F } \\
\text { GTGGAGAGCTGAAGTTTCTCTGC-R }\end{array}$ & Ipa $H$ & 54 & 933 & [9] \\
\hline Inv & $\begin{array}{l}\text { ATATCTCTATTTCCAATCGCGT-F } \\
\text { GATGGCGAGAAATTATATCCCG-R }\end{array}$ & Inv & 54 & 382 & {$[11]$} \\
\hline Int 1 & $\begin{array}{c}\text { TCGGTCAAGGTT-F } \\
\text { AACTTTCAGCACATG-R }\end{array}$ & Int 1 & 50 & 923 & U12338 \\
\hline
\end{tabular}


Electrophoresis was carried out in 1.5\% agarose .The gel was observed under UV light and image captured using a digital camera. Statistical analysis was conducted using the SPSS Version 20.0 software.

\subsection{Statistical Analysis}

Statistical analysis was conducted using the SPSS Version 20.0 software.

\section{Results}

\subsection{Coliforn Forming Units (CFUs) across the Sites}

Results for CFUs from this study had been published work previously [12] but the importance of the data plays a role in accessing the contamination of the river and therefore the data will be shown in order to get clear picture. Sewage effluent area had the highest mean $E$. coli counts of $9.5 \times 10^{3}$ while near virgin land had the lowest mean of $9.5 \times 10^{2}$ as shown in Figure 2 .

\subsection{Prevalence of Extended Spectrum Beta Lactamases (ESBLs)}

There were a total of 7 out of $318 E$. coli isolates that were ESBL-producer (2.2\%). Figure 3 shows an isolate that was an ESBL producer. ESBLs hydrolyse third generation cephalosporins and azreonam but are inhibited by clavulanic acid.

\subsection{Resistance Genes and Integron Class 1 across the Sites}

E. coli isolates that had resistance genes $b l a_{T E M}, b l a_{C T X-M}$ and $b l a_{C M Y}$ were 265 $(83 \%)$ and those that had no resistance genes were $53(17 \%) . B a_{C T X-M}$ had the highest prevalence of 106 (33\%) while bla $a_{T E M}$ had lowest prevalence of 70 (22\%). Resistance genes $b l a_{T E M}, b l a_{C T X-M}$ and $b l a_{C M Y}$ were highest in sewage effluent and

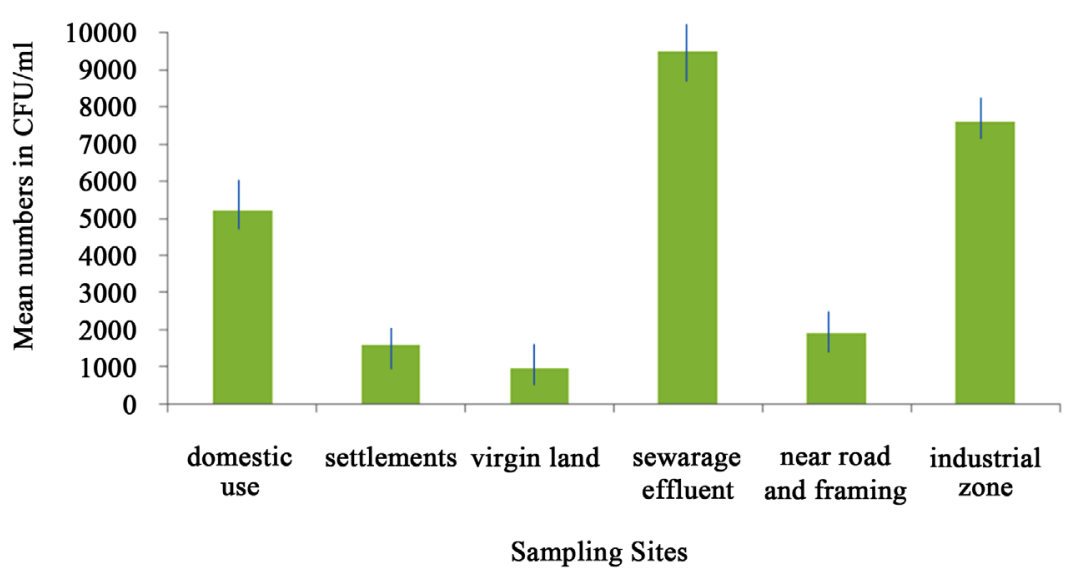

Figure 2. Mean E. coli (CFUs/ml) across the six sites: Activities on sites were; Domestic use site: water used for domestic use, washing clothes, Settlements site: Informal and formal settlements, Virgin land site: No apparent human, industrial or agricultural activities, Sewage effluent site: Sewage treatment plant in close vicinity, Near road and farming: Close to tarmac road water also used for flower farming, Industrial zone: Near the industrial zone water also used for watering flowers. 


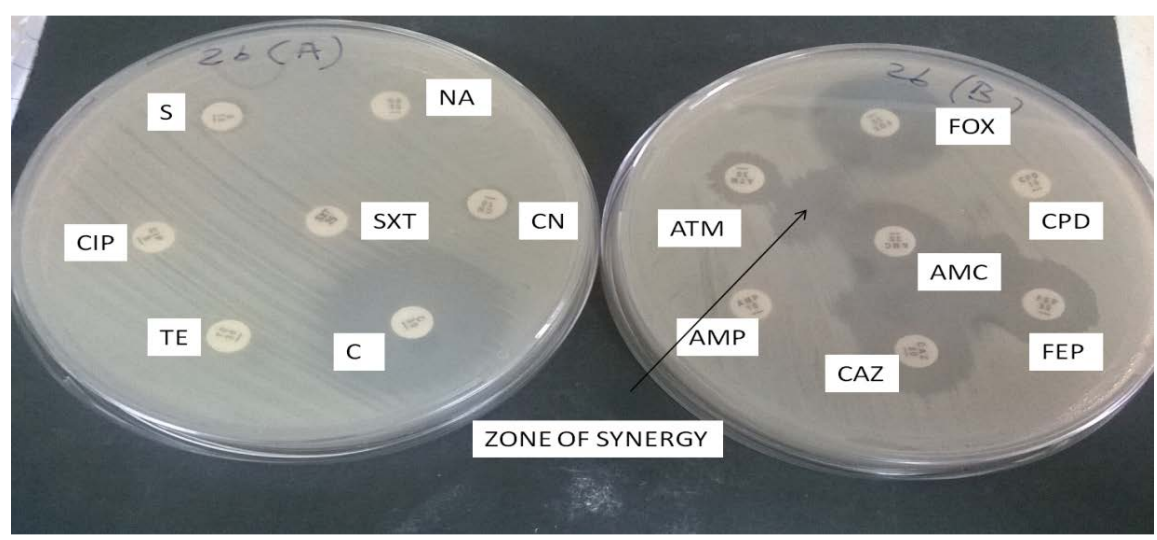

Figure 3. Disk diffusion showing a phenotypic ESBL producer. E. coli isolate isolated from water near industrial zone was resistant to most antimicrobials with exception to Chloramphenicolon plate (1) on the left while on right plate (2), zone of synergy was noted between amoxicillin/clavulanic acid (AMC) in the middle and cefoxtin (FOX) and aztreonam (ATM). N. B Amp: Ampicillin, Fox: Cefoxitin, Caz: Ceftazidime, Fep: Cefepime, Atm: Aztreonam, Amc: Amoxicillin/clavulanic acid, Cip: Ciprofloxacin, S: Streptomycin, Na: Nalidixic, Cn: Gentamicin, C: Chloramphenicol, Te: Tetracycline, Sxt: Trimethoprim-Sulfamethoxazole, Cpd: Cefpodoxim.

near road and farming while $b l a_{C M Y}$ gene was relatively higher near sewage effluent $32(12 \%)$ and near road and farming 27 (10.2\%). bla TEM $_{T E}$ had lower prevalence compared to the other two across sites as shown in Figure 4. Of the total isolates analysed, 114 (36\%) had integron 1 while 204 (64.0\%) did not have integron 1. Integron 1 gene was highest in near sewage effluent 11(30.6\%) and lowest in site where water is used for domestic purposes 3(8.3\%) as shown in Figure 5. Table 2 summarizes the mean CFUs, ESBL, resistance genes and integron1that were found across the sites. Gel images for resistance genes $b a_{C M Y}$, $b l a_{T E M}$ and $b l a_{C T X-M}$ are shown in Figure 6 and Figure 7. Gel image of integron 1 gene is shown in Figure 8.

\subsection{Distribution of Pathotypes}

Isolates that harbored virulence genes were 140 (44\%) while those that did not have any virulence genes were 178 (56\%). EAEC pathotype had the highest prevalence of 35 (25.0\%) while atypical EPEC had the lowest prevalence of 6 (4.3\%). EAEC pathotype was highest near road and farming site and were not isolated in site used for domestic purposes. AIEC pathotype with inv gene were most in virgin land and not present in industrial zone as shown in Figure 9. Gel images for virulence genes are shown in Figure 10 and Figure 11.

\section{Discussion}

The resistance genes that were isolated from this study were $b a_{T E M}(22 \%)$, $\operatorname{bla}_{C T X-M}(33 \%)$ and $b a_{C M Y}(28 \%)$. Evidence has shown that antibiotic resistant bacteria and antibiotic resistance genes (ARGs) are ubiquitous in natural environments, including sites considered pristine. This finding is similar to this study because AGR genes were found in virgin land [13]. A study done in China 


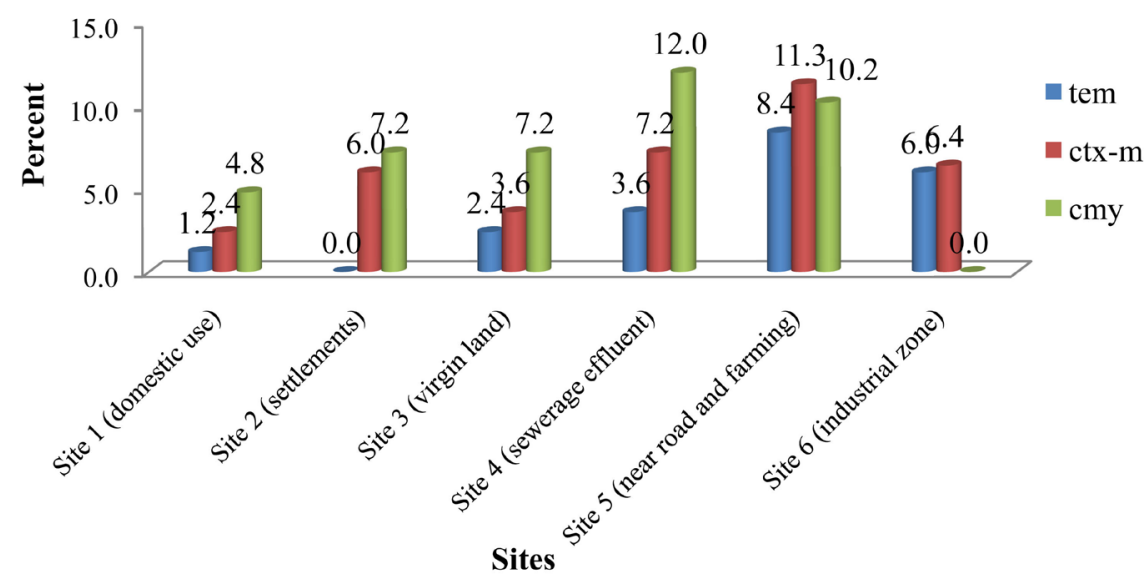

Figure 4. Distribution of resistance genes across sites. PCR analysis of bla $_{T E M}$, bla $_{C T X-M}$ and $b l a_{C M Y}$ genes across the sites. The values on bars are the percentages obtained. These genes are responsible for resistance against ampicillin, cefotaxime and cefoxitin respectively.

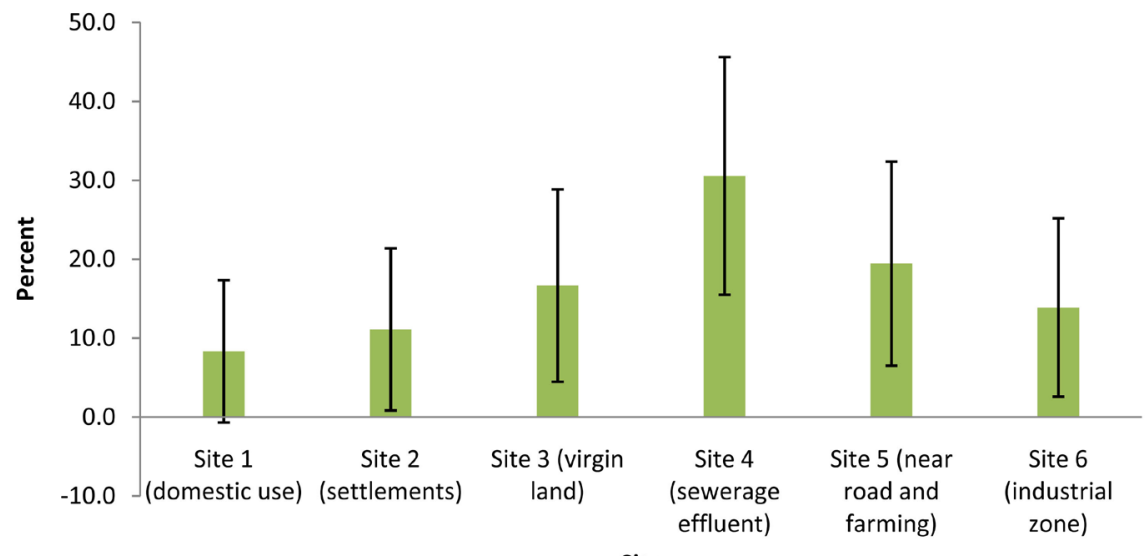

Site

Figure 5. Distribution of integron 1 across sites: PCR analysis using primers for int1 gene. A total of 318 isolates were analyzed. The bar graph shows error bars from percentage using $95 \% \mathrm{CI}$.

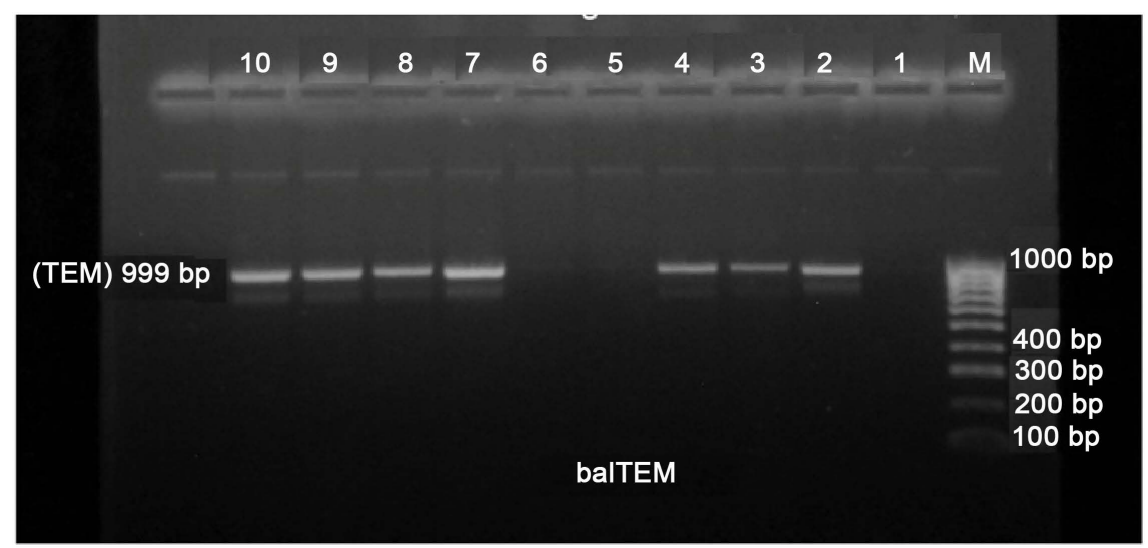

Figure 6. Gel image showing bla $_{T E M}$ gene. (M)-ladder 1-negative control, 2-positive control 3 and 4 positive isolates from human settlements, isolate 7 from sewage effluent and isolates 8 and 9 from near road and farming, wells 5 and 6 were empty. 


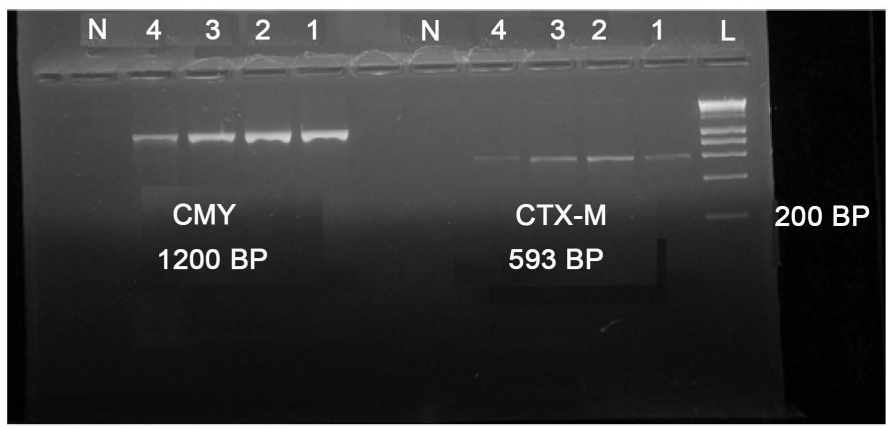

Figure 7. Gel image showing $b a_{C M Y}$ and $b l_{C T X-M}$ genes: L-ladder, N-negative control for bla $_{C M Y}$ gene on the left, 1 to 3 are positive isolates from seawage effluent. 4-positive control while on right $b_{C T X-M}$ gene 1 to 3 isolates positive from sewage effluent and 4-positive control.

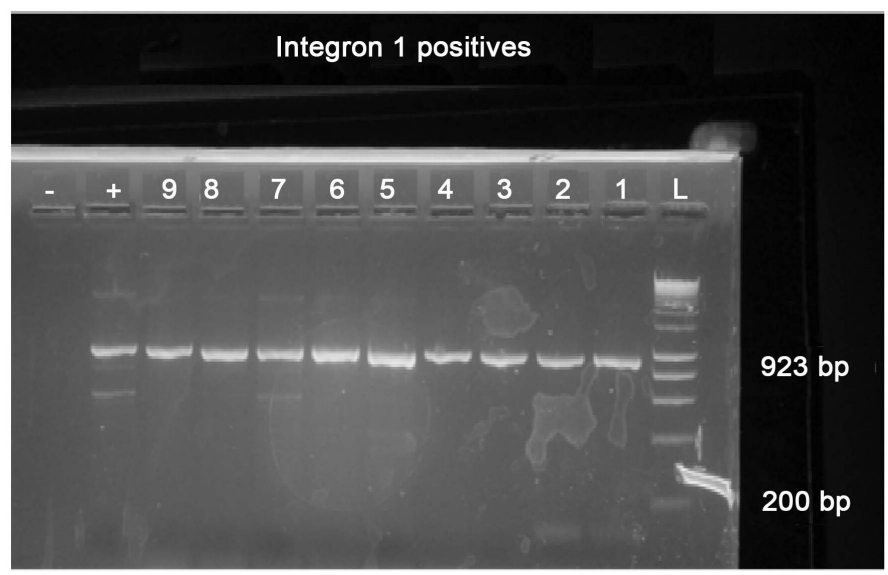

Figure 8. Positive PCR products of int1 gene amplification. E. coli isolates positive for int 1 from near settlements and industrial zone sampled. (-) Negative control, (+) positive control, (L) ladder ( 1 - 9) isolates positive for int 1 at $923 \mathrm{bp}$.

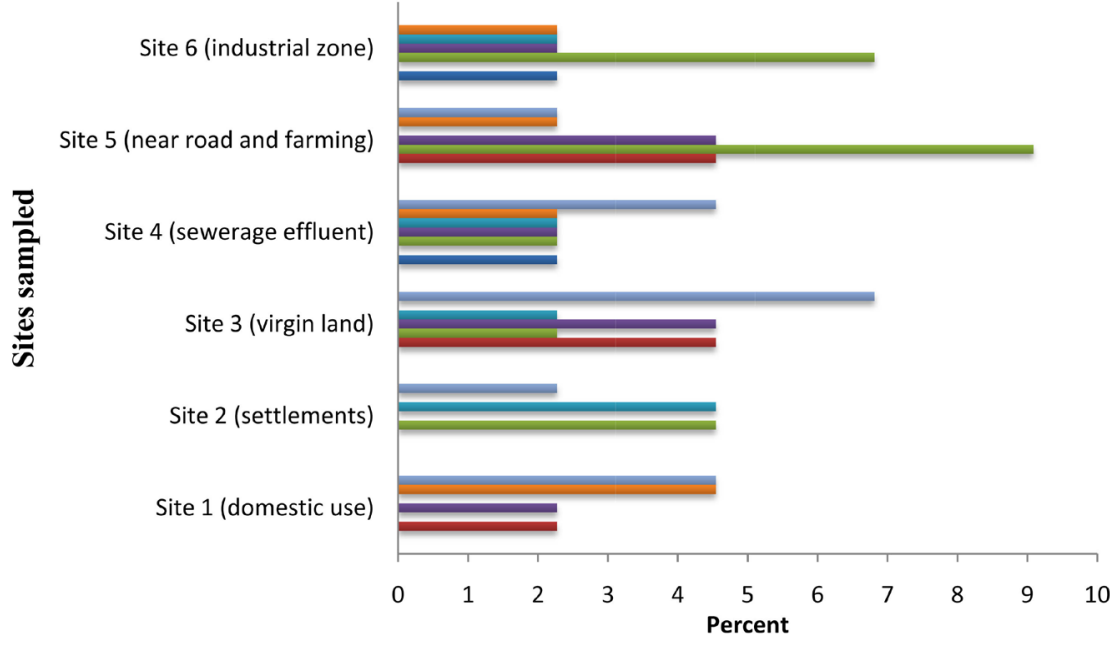

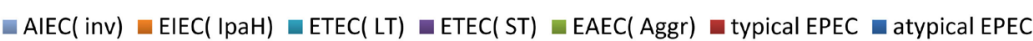

Figure 9. Distribution of pathotypes across sites. Distribution of inv, ipaH, lt, st, aggr, bfp and eae genes across sites sampled in the study. Aggr gene for EAEC pathotype has highest in site near road and farming. 
Table 2. Mean CFUs, ESBL, resistance genes and integron 1 across sites.

\begin{tabular}{|c|c|c|c|c|c|c|c|}
\hline site & $\begin{array}{l}\text { Mean } \\
\text { cfus }\end{array}$ & $\begin{array}{l}\text { No. of isolates } \\
\text { analysed }\end{array}$ & $\begin{array}{l}\text { ESBL } \\
\text { n (\%) }\end{array}$ & $\begin{array}{l}b l a^{T E M} \\
\mathrm{n}(\%)\end{array}$ & $\begin{array}{c}b l a c T X-M \\
\mathrm{n}(\%)\end{array}$ & $\begin{array}{l}b l a^{C M Y} \\
\mathrm{n}(\%)\end{array}$ & $\begin{array}{c}\text { Integron } \\
\text { 1n (\%) }\end{array}$ \\
\hline Domestic use & $5.2 \times 10^{3}$ & 53 & $0(0)$ & $3(1)$ & $6(2)$ & $13(5)$ & $3(8.3)$ \\
\hline settlements & $1.6 \times 10^{3}$ & 53 & $2(0.6)$ & $0(0)$ & $16(6)$ & $19(7)$ & $4(11.1)$ \\
\hline Virgin land & $9.5 \times 10^{2}$ & 53 & $1(0.3)$ & $6(2)$ & $10(3)$ & $19(7)$ & $6(16.7)$ \\
\hline Sewerage effluent & $9.5 \times 10^{3}$ & 53 & $2(0.6)$ & $10(3)$ & $19(7)$ & $32(12)$ & $11(30.6)$ \\
\hline Near road and farming & $1.9 \times 10^{3}$ & 53 & $0(0)$ & $22(7)$ & $30(11)$ & $27(12)$ & $7(19.4)$ \\
\hline Industrial zone & $7.6 \times 10^{3}$ & 53 & $2(0.6)$ & $16(5)$ & $17(10)$ & $0(0)$ & $5(13.9)$ \\
\hline
\end{tabular}

CFUs were highest in area near sewage effluent which also harboured the highest number of integronl gene. Areas near road and farming had the highest number $b l a^{T E M}$ and $B l a^{C M Y}$ genes. ESBLs were found in equal numbers in areas close to human settlements, near sewage effluent and area near industrial zone.

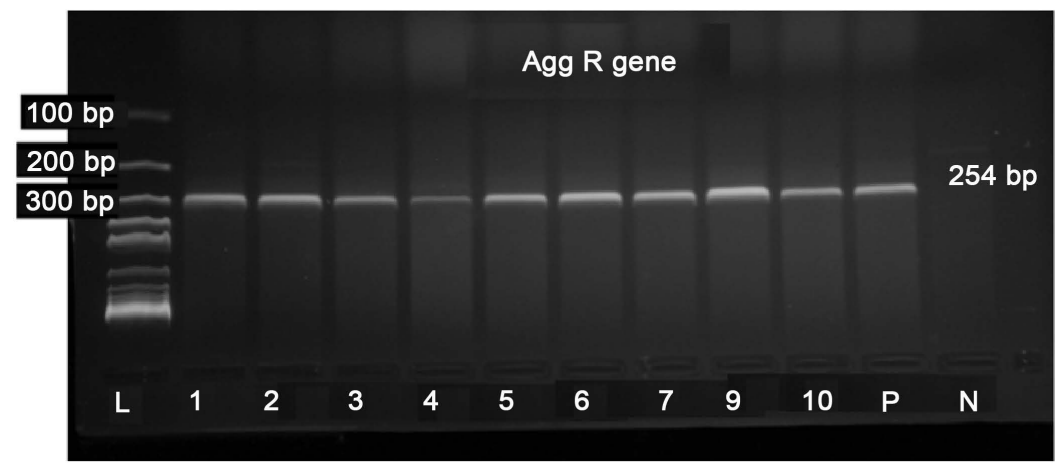

Figure 10. Gel image showing aggregative gene (aggr) E. coli isolates. EAEC pathotype carrying Aggregrative gene (aggr) bp 254 from E. coli isolated from close proximity to sewage treatment plant $(\mathrm{L})$ ladder $(\mathrm{P})$ positive control $(\mathrm{N})$ negative control $(1-10)$ E. coli isolates.

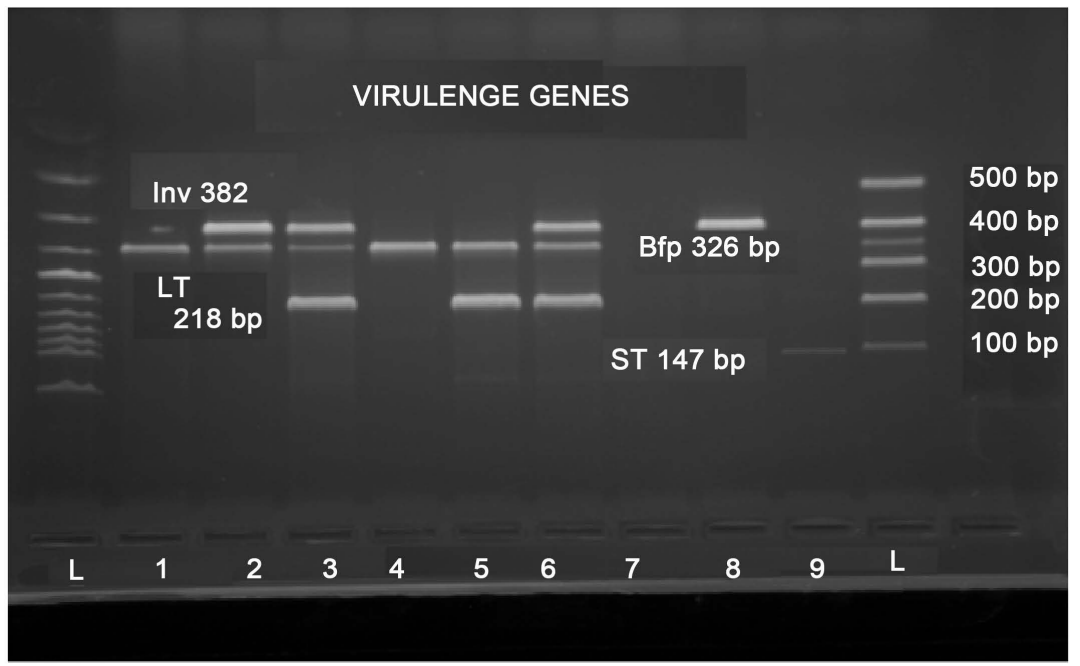

Figure 11. Gel image representing inv, lt, st and bfp virulence genes. Summary gel showing multiplex PCR for various pathotypes: AIEC pathotype inv positive at bp 382 (isolate 2, 3 and 6; 8-positive control, 9-negative control) and ETEC pathotype with lt gene at 218 bp (positive control isolate 3, negative control 4; isolates 5 and 6 from human settlements and ST gene at $147 \mathrm{bp}$, typical EPEC that had bfp gene at $326 \mathrm{bp}(1-5)$ positive isolates from sewage effluent 6-positive control, 7-negative control (L) ladder. 
supported the theory of bacterial resistance being strongly influenced by discharge of waste water [14].

Both $b l a_{T E M}$ and $b l a_{S H V}$ genes have been reported mostly from clinical samples and from environmental samples like farm animals and estuarine waters. Interestingly, majority of the isolates in this study were positive for bla $_{C T X-M}$ while none were positive for $b l a_{S H V}$. The abundance of $b a_{C T X-M}$ in aquatic environments has been reported in other studies done in Switzerland and Malaysia [15] [16].

Entero aggregative E. coli (EAEC) had the highest prevalence (11\%) compared to other pathotypes screened in this study. Although no study in Kenya has analyzed prevalence of diarrheagenic $E$. coli in river water, our findings concur with others done in Kenya using clinical isolates. A recent study in Kenya demonstrated EAEC (8.9\%), as the most frequent followed by ETEC (1.2\%) and EIEC (0.6\%) [17]. A similar study on shigatoxigenic E. coli from in Maasailand, Kenya, revealed a different scenario with ETEC (29.8\%), EHEC (24\% , EAEC (14.2\%) and EPEC (3.5\%) being identified [18].

Pathogenic E. coli has also been isolated in other studies from river water [19]. Presence of pathogenic E. coli in water creates a potential risk for infections in humans and animals especially if the water is used for irrigation, drinking and for recreational purposes [20] [21] [22]. Increase in presence of multi-drug resistant pathogenic E. coli in water that was seen in San Pedro River in Mexico [23] as well as in India where surface, municipal and ground water were collected [24].

It is likely that multiple exposure pathways are involved in transmitting pathogenic E. coli to humans and river water play a significant role as it is highly contaminated. While the presence of virulence genes (VGs) in E. coli isolates alone is insufficient to determine pathogenicity, the presence of diarrheagenic E. coli pathotypes in high frequency could lead to increased health risks if untreated rain water were to be used for nonpotable purposes and recreational activities.

The prevalence of integron 1 was $36 \%$ in this study. The int 1 gene was found mostly near sewage treatment plant as well as after the treatment plant. This could be attributed by the effluent of the treatment plant becoming a reservoir of int 1 gene. This phenomenon was described by a previous study done in Poland [21] where the number of integron 1 genes were higher downstream the discharge of WWTPS effluent [21]. Integron 1 in E. coli from aquatic environment has also been reported in previous study done in Kenya using water from different sources $(47.4 \%, 18 / 38)$ [25] which was higher compared to this study. More so, in China, $41 \%$ of $E$. coli from Minjiang River harboured int 1 [26].

\section{Conclusions}

E. coli isolates harboured resistance genes, virulence genes and integron class 1 genes. Resistance genes, virulence genes and integron class 1 were more near the sewage effluent and therefore there is a need to decontaminate the area. From this study therefore, it can be concluded that anthropogenic activities along wa- 
ter bodies can play a role in the contamination of water and spread of antimicrobial resistance genes and virulence genes. Because river water flows from upstream to downstream, activities done upstream have potential to affect people living many kilometres downstream of the river who use the water for drinking, farming and other recreational purposes

The sewage treatment plant played a key role in contamination of the river and isolation of resistance and virulence genes. Better treatment and quality control of waste water should be emphasized in this region and more modern technologies employed in the sewage treatment plant which can help to remove contaminants together with virulence and resistance genes from waste water. It should be noted that however, chemical disinfection methods may cause an undesirable selection of antimicrobial resistance by themselves as seen in previous studies.

\section{Acknowledgements}

I would like to thank centre of microbiology in Kenya medical research institute personnel for offering me lab space and equipments. The work was supported by National Council for Science and Technology (NACOSTI).

\section{Authors' Contribution}

PW came up with the concept for the work and designed the study. She did the lab work and drafted the manuscript. JK participated in the study design and helped in drafting the manuscript. VM corrected the proposal and helped in its coordination. All authors read and approved final manuscript.

\section{Authors' Information}

PW is a master's student in Kenya studying medical microbiology, Prof. VM is the dean of biological sciences in Jomo Kenyatta University of agriculture and technology who has a vast experience in proposal development and microbial techniques and Dr. JK is a researcher in Centre of Microbiology Research Centre in Kenya Medical Research Institute. He helped in actualizing the study and fine tuning the manuscript

\section{Conflicts of Interest}

The authors declare there is no conflict of interest regarding the publishing of this manuscript.

\section{Ethical Approval}

Approved.

\section{References}

[1] Molloy, S.L., Whitman, R.L., Shively, D.A., Nevers, M.B., Schwab, D.J. and Rose, J.B. (2006) Modeling the Transport and Inactivation of E. coli and Enterococci in 
the Near-Shore Region of Lake Michigan. Environmental Science and Technology, 40, 5022-5028. https://doi.org/10.1021/es060438k

[2] Hawkey, P.M., Jones, A.M., Birmingham, B., Strategic, M. and House, M. (2009) The Changing Epidemiology of Resistance. Antimicrobial Chemotherapy, 64, 3-10. https://doi.org/10.1093/jac/dkp256

[3] WHO (2006) Guidlines for the Safe Use of Waste Water, Excreta and Grey Water. Wastewater Use in Agriculture, Vol. 2.

[4] Holt, K.E., Wertheim, H., Zadoks, R.N., Baker, S., Whitehouse, C.A. and Dance, D. (2015) Genomic Analysis of Diversity, Population Structure, Virulence, and Antimicrobial Resistance in Klebsiella pneumoniae, an Urgent Threat to Public Health. PNAS, 112, E3574-E3581. https://doi.org/10.1073/pnas.1501049112

[5] Coutinho, F.H., Pinto, L.H., Vieira, R.P., Martins, O.B., Rhayd, G., Salloto, B. and Cardoso, A.M. (2013) Antibiotic Resistance in Aquatic Environments of Rio de Janeiro, Brazil. INTECH, 1-22.

[6] Musyoki, A.M., Suleiman, M.A., Mbithi, J.N. and Maingi, J.M. (2013) Water-Borne Bacterial Pathogens in Surface Waters of Nairobi River and Health Implications to Communities Downstream Athi River. International Journal of Life Science and Pharma Research, 3, L-4-L-10.

[7] Versalovic, J., Koeuth, T. and Lupski, J.R. (1991) Distribution of Repetitive DNA Sequences in Eubacteria and Application to Fingerprinting of Bacterial Genomes. Nucleic Acids Research, 19, 6823-6831.

[8] Aranda, K.S., Fabbricotti, S.H., Fagundes-neto, U. and Scaletsky, I.A. (2007) Single Multiplex Assay to Identify Simultaneously Enteroinvasive and Shiga Toxin-Producing Escherichia coli Strains in Brazilian Children. FEMS Microbiology Letters, 267, 145-150. https://doi.org/10.1111/j.1574-6968.2006.00580.x

[9] Vidal, R. (2005) Single Multiplex PCR Assay to Identify Simultaneously the Six Categories of Diarrheagenic Escherichia coli Associated with Enteric Infections. Journal of Clinical Microbiology, 43, 5362-5365. https://doi.org/10.1128/JCM.43.10.5362-5365.2005

[10] Naser, L.A., Mahdi, K.H. and Almazini, M.A. (2016) Determination the Effect of ST Enterotoxin Isolated from Enterotoxigenic Escherichia coli Strains on Colon Cancer from Diarrhea Patients in Basra Hospitals. International Journal of Innovative Research in Science, Engineering and Technology, 5, 2742-2756.

[11] Beata, S.A., Michai, T., Franiczek, R.U.K., Anna, D.K., Rzeszutko, M. and Iwańczak, B. (2012) Invasive Properties, Adhesion Patterns and Phylogroup Profiles among Escherichia coli Strains Isolated from Children with Inflammatory Bowel Disease. Advances in Clinical and Experimental Medicine, 21, 591-599.

[12] Wambugu, P., Habtu, M., Impwi, P., Matiru, V. and Kiiru, J. (2015) Antimicrobial Susceptibility Profiles among Escherichia coli Strains Isolated from Athi River Water in Machakos County, Kenya. Advances in Microbiology, 5, 711-719. https://doi.org/10.4236/aim.2015.510074

[13] Knapp, C.W., Lima, L., Olivares-Rieumont, S., Bowen, E., Werner, D. and Graham, D.W. (2012) Seasonal Variations in Antibiotic Resistance Gene transport in the Almendares River, Havana, Cuba. Frontiers in Microbiology, 3, 396

[14] Su, H., Ying, G., Tao, R., Zhang, R., Zhao, J. and Liu, Y. (2012) Class 1 and 2 Integrons, sul Resistance Genes and Antibiotic Resistance in Escherichia coli Isolated from Dongjiang River, South China. Environmental Pollution, 169, 42-49. https://doi.org/10.1016/j.envpol.2012.05.007

[15] Zurfluh, K., Hächler, H., Nüesch-Inderbinen, M. and Stephan, R. (2013) Carbap- 
enemase-Producing Enterobacteriaceae Isolates from Rivers and Lakes in Switzerland. Applied and Environmental Microbiology, 79, 3021-3026. https://doi.org/10.1128/AEM.00054-13

[16] Shehani, T. and Lee, S.M. (2013) Isolation of Extended Spectrum $\beta$-Lactamase (ESBL) Producing Bacteria from Urban Surface Waters in Malaysia. Malaysian Journal of Medical Sciences, 20, 14-22.

[17] Sang, W.K., Oundo, V. and Schnabel, D. (2012) Prevalence and Antibiotic Resistance of Bacterial Pathogens Isolated from Childhood Diarrhoea in Four Provinces of Kenya. Journal of Infection in Developing Countries, 6, 572-578. https://doi.org/10.3855/jidc. 2196

[18] Sang, W.K., Boga, H.I., Waiyaki, P.G., Schnabel, D., Wamae, N.C. and Kariuki, S.M. (2012) Prevalence and Genetic Characteristics of Shigatoxigenic Escherichia coli from Patients with Diarrhoea in Maasailand, Kenya. Journal of Infection in Developing Countries, 6, 102-108. https://doi.org/10.3855/jidc.1750

[19] Ndlovu, T., Le Roux, M., Khan, W. and Khan, S. (2015) Co-Detection of Virulent Escherichia coli Genes in Surface Water Sources. PLoS ONE, 10, e0116808. https://doi.org/10.1371/journal.pone.0116808

[20] Hamelin, K., Bruant, G., El-shaarawi, A., Hill, S., Edge, T.A., Fairbrother, J. and Brousseau, R. (2007) Occurrence of Virulence and Antimicrobial Resistance Genes in Escherichia coli Isolates from Different Aquatic Ecosystems within the St. Clair River and Detroit River Areas. Applied and Environmental Microbiology, 73, 477-484. https://doi.org/10.1128/AEM.01445-06

[21] Koczura, R., Mokracka, J., Jabłońska, L., Gozdecka, E., Kubek, M. and Kaznowski, A. (2012) Antimicrobial Resistance of Integron-Harboring Escherichia coli Isolates from Clinical Samples, Wastewater Treatment Plant and River Water. The Science of the Total Environment, 414, 680-685. https://doi.org/10.1016/j.scitotenv.2011.10.036

[22] Kummerer, K. (2009) Chemosphere Antibiotics in the Aquatic Environment-A Review-Part I. Chemosphere, 75, 417-434. https://doi.org/10.1016/j.chemosphere.2008.11.086

[23] Castillo, F.Y.R., González, F.J.A., Garneau, P., Díaz, F.M., Barrera, A.L.G., Harel, J. and De, I.N. (2013) Presence of Multi-Drug Resistant Pathogenic Escherichia coli in the San Pedro River Located in the State of Aguascalientes, Mexico. Frontiers in Microbiology, 4, 1-16.

[24] Varghese, M. and Roymon, M.G. (2013) Studies on Antibiotic Resistance Profiles of Thermotolerant Escherichia coli and Multiple Antibiotic Resistance Index of Different Water Sources. Recent Research in Science and Technology, 5, 68-72.

[25] Njugu, P.M. (2011) Antibiotic Susceptibility Patterns and Detection of Genes Responsible for the Resistance of Klebsiella Species and Escherichia coli. Thesis Copy from JKUAT Library.

[26] Chen, B., Zheng, W., Yu, Y., Huang, W., Zheng, S., Zhang, Y. and Topp, E. (2011) Class 1 Integrons, Selected Virulence Genes, and Antibiotic Resistance in Escherichia coli Isolates from the Minjiang River, Fujian Province, China. Applied and Environmental Microbiology, 77, 148-155.

https://doi.org/10.1128/AEM.01676-10 